\title{
Substitusi Tepung Kedelai dengan Tepung Daun Eceng Gondok (Eichhornia crassipes) Terfermentasi untuk Pertumbuhan Benih Ikan Mas (Cyprinus Carpio)
}

\author{
Substitution of Soybean Flour with Fermented Water Hyacinth Leaf Flour \\ (Eichhornia crassipes) for the Growth of Common Carp (Cyprinus Carpio) \\ Febri Ridho Putra ${ }^{1 *}$, Indra Suharman ${ }^{1}$, Adelina ${ }^{1}$ \\ ${ }^{1}$ Jurusan Budidaya Perairan, Fakultas Perikanan dan Kelautan, Universitas Riau \\ email:febriridho@gmail.com
}

(Received: 01 Juni 2021; Accepted: 25 Juni 2021)

\begin{abstract}
ABSTRAK
Eceng gondok (Eichhornia crassipes) merupakan tanaman air yang memiliki kemampuan berkembang biak dengan cepat dan memiliki nutrisi yang dibutuhkan ikan. Penelitian ini bertujuan untuk mengevaluasi pengaruh penggunaan tepung daun eceng gondok difermentasi kombucha dalam pakan untuk pertumbuhan benih ikan mas dan dapat mengetahui dosis yang optimal. Penelitian ini dilaksanakan pada bulan Januari - Februari 2020, persiapan bahan pakan dilakukan di Laboratorium Nutrisi Ikan Fakultas Perikanan dan Kelautan Universitas Riau. Pemeliharaan ikan dilakukan di Balai Benih Ikan Sei Tibun, Kabupaten kampar, Riau, sedangkan untuk uji proksimat pakan dilakukan di Laboratorium Analisis Hasil Pertanian, Fakultas Pertanian, Universitas Riau. Ikan uji yang digunakan dalam penelitian ini adalah benih ikan mas (Cyprinus carpio) dengan berat rata-rata 4,5 $\pm 0,2 \mathrm{~g}$ sebanyak 475 ekor. Perlakuan pada penelitian ini adalah sebagai berikut P0 (Tepung eceng gondok 0\%: tepung kedelai 100\%), P1 (25\%:75\%), P2 (50\%:50\%), P3 (75\%:25\%), dan P4 (100\%:0\%). Hasil penelitian menunjukkan bahwa subtitusi tepung eceng gondok dan tepung kedelai memberikan pengaruh terhadap laju pertumbuhan dan kelulushidupan ikan mas $(\mathrm{p}<0,05)$. Hasil terbaik terdapat pada P2 (Tepung eceng gondok 50\%: tepung kedelai $50 \%$ ) dengan nilai kecernaan pakan $(68,94 \%)$, kecernaan protein $(85,01 \%)$, nilai efisiensi pakan $(32,80 \% \pm 2,03)$, retensi protein $(52,45 \% \pm 3,21)$, laju pertumbuhan spesifik $(2,76 \%$ /hari), dan Kelulushidupan $100 \%$. Kesimpulan dari penelitian menunjukkan bahwa tepung eceng gondok terfermentasi sebanyak 50\% mampu menggantikan tepung kedelai dalam pemeliharaan ikan mas.
\end{abstract}

Kata Kunci: Eceng gondok, Ikan mas, Kombucha, Fermentasi

\begin{abstract}
Water hyacinth (Eichhornia crassipes) is an aquatic plant that has the ability to reproduce quickly and has the nutrients that fish need. This study aims to evaluate the effect of using kombucha fermented water hyacinth leaf meal in feed for the growth of common carp fingerling and to determine the optimal dosage. This research was conducted in January - February 2020, the preparation of feed ingredients was carried out at the Fish Nutrition Laboratory, Faculty of Fisheries and Marine, Universitas Riau. Fish rearing is carried out at the Sei Tibun Fish Center, Kampar Regency, Riau, while the proximate feed test is carried out at the Agricultural Product Analysis Laboratory, Faculty of Agriculture, Riau University. The test fish used in this study were 475 common carp with an average weight of $4.5 \pm 0.2 \mathrm{~g}$. The treatments in this study were as follows P0 (0\% water hyacinth flour: $100 \%$ soybean flour), P1 (25\%: $75 \%)$, P2 (50\%: 50\%), P3 (75\%: 25\%), and P4 (100\%: 0\%). The results showed that the substitution of water hyacinth flour and soybean flour had an effect on the growth rate and survival of common carp ( $\mathrm{p}<0.05)$. The best results were found in P2 (50\% water hyacinth flour: 50\% soybean flour) with feed digestibility (68.94), protein digestibility (85.01), feed efficiency values $(32.80 \pm 2.03)$, protein retention. (52.45
\end{abstract}


$\pm 3.21)$, specific growth rate $(2.76 \%$ / day), and survival rate $100 \%$. The conclusion of the study shows that $50 \%$ fermented water hyacinth flour can replace soybean flour in common carp rearing.

Keyword: Water hyacinth, common carp, Kombucha, Fermentation

\section{Pendahuluan}

Ikan mas (Cyprinus carpio) merupakan salah satu komoditas perikanan air tawar yang saat ini menjadi primadona di sub sektor perikanan. Ikan ini di pasaran memiliki nilai ekonomis tinggi. Menurut Pratama et al. (2015) menyatakan bahwa kandungan gizi pada ikan mas yaitu kadar protein 15,23$17,83 \%$, kadar lemak 3,53-8,3\% dan karbohidrat 0,5 -1,5\%.

Pakan merupakan komponen utama yang menjadi penunjang kelangsungan usaha budidaya. Biaya terbesar dalam usaha budidaya ikan berasal dari pakan, yaitu dapat mencapai $60-70 \%$ dari total biaya produksi (Suprayudi, 2010). Salah satu upaya untuk mengurangi ketergantungan pada bahan baku impor seperti tepung kedelai adalah melakukan penggantian dengan bahan pakan lokal yang memiliki kandungan nutrien yang dibutuhkan ikan dalam jumlah yang cukup, harga lebih murah, tersedia dalam jumlah besar, dan tidak berkompetisi dengan manusia serta untuk mendapatkannya terjamin kontinuitasnya seperti eceng gondok (Eichhornia crassipes).

Eceng gondok merupakan tanaman air yang dapat berkembang biak dengan cepat dan mampu bersaing kuat dengan organisme perairan lainnya, sehingga umumnya disebut sebagai gulma. Eceng gondok memiliki protein berkisar 9,8 - 15,7\%, abu 11,9 23,9\%, lemak kasar 1,1-3,3\%, dan serat kasar 16,8-24,6\% (Astuti, 2008). Kendala pemakaian tepung daun eceng gondok sebagai bahan baku pakan adalah adanya zat antinutrisi berupa nitrat $0,3 \%$, oksalat $0,6 \%$ dan sianida $30 \mathrm{mg} / \mathrm{kg}$ basah. Pada konsentrasi yang berlebih zat antinutrisi tersebut dapat menyebabkan nekrosis pada organ pencernaan dan penurunan pertumbuhan ikan (Muskita, 2012). Oleh sebab itu, perlu dilakukan pengolahan terhadap eceng gondok tersebut sebelum digunakan sebagai bahan pakan. Untuk meningkatkan nilai gizi dan meningkatkan kecernaan eceng gondok dapat dilakukan melalui teknologi fermentasi (Fitrihidajati et al., 2015).
Salah satu fermentor yang dapat digunakan adalah kombucha. Penggunaan kombucha pada daun talas selama 14 hari terbukti dapat meningkatkan protein kasar dari $29 \%$ menjadi $32,71 \%$ dan menurunkan serat kasar dari 22,17\% menjadi 15,78\% (Priskila, 2007). Berdasarkan uraian diatas, maka penulis tertarik untuk melakukan penelitian mengenai substitusi tepung kedelai dengan tepung daun eceng gondok terfermentasi

Penelitian ini bertujuan untuk mengevaluasi pengaruh penggunaan tepung daun eceng gondok difermentasi kombucha dalam pakan untuk pertumbuhan benih ikan mas dan dapat mengetahui dosis yang optimal untuk pertumbuhan benih ikan mas.

\section{Metode Penelitian}

\subsection{Waktu dan Tempat}

Penelitian ini dilaksanakan pada bulan Januari - Februari 2020 dimulai dari persiapan bahan pakan dilakukan di Laboratorium Nutrisi Ikan Fakultas Perikanan dan Kelautan Universitas Riau. Pemeliharaan ikan dilakukan di Balai Benih Ikan Sei Tibun, Kabupaten kampar, Riau, sedangkan untuk uji proksimat pakan dilakukan di Laboratorium Analisis Hasil Pertanian, Fakultas Pertanian, Universitas Riau.

\subsection{Metode Penelitian}

Metode yang digunakan dalam penelitian adalah metode eksperimen dengan menggunakan Rancangan Acak Lengkap (RAL) satu faktor dengan 5 taraf perlakuan dan 3 kali ulangan sehingga diperlukan 15 unit percobaan. Adapun perlakuan yang digunakan mengacu pada (Trivela, 2018) adalah sebagai berikut:

$\mathrm{P0}=$ Tepung kedelai 100\%: Tepung daun eceng gondok terfementasi $0 \%$

$\mathrm{P} 1=$ TK 75\%: TDEGF $25 \%$

$\mathrm{P} 2=$ TK 50\%: TDEGF 50\%

$\mathrm{P} 3=$ TK 25\%: TDEGF 75\%

$\mathrm{P} 4=$ TK 0\%: TDEGF $100 \%$ 


\subsection{Prosedur Penelitian}

\subsubsection{Persiapan Wadah}

Wadah yang akan digunakan dalam penelitian ini adalah keramba yang terbuat dari jaring kasa dengan mesh size $1 \mathrm{~mm}$ dan akuarium. Keramba yang digunakan berukuran $1 \times 1 \times 1 \mathrm{~m}^{3}$ dipasang dan disusun sedemikian rupa pada kolam penelitian. Setiap perlakuan diacak menurut wadah yang telah disusun sebanyak 15 buah. Sementara akurium yang digunakan berukuran 60x40x40 $\mathrm{cm}$ sebanyak 10 unit. Akuarium ini digunakan sebagai media untuk mengamati kecernaan pakan ikan. Sebelum akuarium tersebut digunakan terlebih dahulu dibersihkan menggunakan larutan PK (kalium permanganat) dan dikeringkan. Setelah itu diisi air dengan volume air $35 \mathrm{~L}$ dan diberikan aerasi.

\subsubsection{Persiapan Eceng Gondok dan Starter Kombucha}

Eceng gondok yang digunakan sebagai suplemen nabati diambil daunnya, setelah itu daun eceng gondok direndam selama 24 jam pada air mengalir, bertujuan untuk menghilangkan zat antinutrisi berupa sianida. Setelah direndam, daun eceng gondok dipotong-potong kecil dan dijemur di bawah sinar matahari hingga layu. Selanjutnya daun eceng gondok dihaluskan /digiling mengguna- kan mesin penepung untuk dijadikan tepung yang nanti difermentasi menggunakan kombucha.

Cara pembuatan starter kombucha mengacu pada (Priskila, 2007) yaitu, air direbus hingga mendidih, setelah itu air yang mendidih diukur sebanyak $500 \mathrm{~mL}$, kemudian 2 cup teh sariwangi celup dimasukkan hingga berubah warna kecoklatan. Lalu dimasukkan $100 \mathrm{~g}$ gula ke dalam larutan teh yang sudah dibuat sebelumnya, aduk hingga gula dan air larut. Kemudian ditimbang kombucha $50 \mathrm{~g}$ lalu dipotong, kemudian masukkan ke dalam larutan teh. Aduk sampai rata larutan teh. Kemudian masukkan larutan teh yang sudah dicampur gula dan kombucha ke dalam toples kaca kemudian tutup rapat, simpan pada suhu kamar selama 8-12 hari , dengan suhu $23-27{ }^{\circ} \mathrm{C}$ tanpa terkena cahaya matahari.

\subsubsection{Pembuatan Pakan Uji}

Isolat A.hydrophila Pakan yang akan dibuat, sebelumnya ditentukan formulasi dan komposisi masing-masing bahan sesuai dengan kebutuhan protein yang diharapkan yaitu sebesar $30 \%$ (Tabel 1). Proporsi fermentasi eceng gondok ditentukan sesuai kebutuhan masing-masing perlakuan, sedangkan bahan-bahan lain disesuaikan jumlahnya berdasarkan hasil perhitungan.

Tabel 1. Komposisi Pakan Uji dan Hasil Proksimat Pakan Uji pada Setiap Perlakuan

\begin{tabular}{|c|c|c|c|c|c|c|}
\hline \multirow{3}{*}{ Bahan } & \multirow{3}{*}{$\begin{array}{c}\text { Protein } \\
\text { Bahan }\end{array}$} & \multicolumn{5}{|c|}{ Perlakuan } \\
\hline & & $\begin{array}{l}\text { P0 (TK)100\% \& } \\
\text { (TDEGF) 0\% }\end{array}$ & $\begin{array}{l}\text { P1 TK }(75 \%) \& \\
\operatorname{TDEGF}(25 \%)\end{array}$ & $\begin{array}{l}\mathrm{P} 2 \text { TK }(50 \%) \& \\
\text { TDEGF }(50 \%)\end{array}$ & $\begin{array}{l}\text { P3 TK }(25 \%) \& \\
\text { TDEGF }(75 \%)\end{array}$ & $\begin{array}{l}\text { P4 TK }(0 \%) \& \\
\text { TDEGF (100) }\end{array}$ \\
\hline & & $\% \mathrm{~B}$ & $\% \mathrm{~B}$ & $\% \mathrm{~B}$ & $\% \mathrm{~B}$ & $\% \mathrm{~B}$ \\
\hline T. Ikan & 59 & 25.0 & 14.8 & 18.3 & 21.2 & 24 \\
\hline TDEG & 20 & 0.0 & 2.3 & 4.5 & 6.8 & 9.0 \\
\hline T. Kedelai & 45 & 45 & 15.2 & 10.1 & 5.1 & 0.0 \\
\hline Dedak & 12 & 12.0 & 1.4 & 1.1 & 0.7 & 0.7 \\
\hline T.Terigu & 12 & 12.0 & 1.4 & 1.1 & 0.8 & 1.0 \\
\hline Vitamin mix & 0 & 2.0 & 0.0 & 0.0 & 0.0 & 0.0 \\
\hline Mineral mix & 0 & 2.0 & 0.0 & 0.0 & 0.0 & 0.0 \\
\hline Minyak ikan & 0 & 2.0 & 0.0 & 0.0 & 0.0 & 0.0 \\
\hline Jumlah & & 100 & 100 & 100 & 100 & 100 \\
\hline Protein & & 32.20 & 32.90 & 33.45 & 33.00 & 32.80 \\
\hline Lemak & & 11.30 & 10.13 & 9.45 & 10.25 & 11.34 \\
\hline Air & & 10.80 & 10.15 & 9.55 & 10.44 & 10.23 \\
\hline $\mathrm{Abu}$ & & 8.20 & 10.88 & 11.87 & 12.50 & 9.13 \\
\hline Serat Kasar & & 8.23 & 7.67 & 5.34 & 7.74 & 7.56 \\
\hline BETN & & 29.27 & 28.27 & 30.34 & 26.07 & 28.94 \\
\hline Total Energi & $1 \mathrm{DE} / \mathrm{g}) *$ & 277.41 & 267.88 & 269.47 & 263.70 & 279.00 \\
\hline $\mathrm{C} / \mathrm{P}(\mathrm{kkal} \mathrm{DE} /$ & & 8.62 & 8.14 & 8.06 & 7.99 & 8.51 \\
\hline
\end{tabular}

Keterangan : TDEGF : Tepung Daun Eceng Gondok Fermentasi, TK : Tepung Kedelai

Bahan-bahan yang digunakan ditimbang sesuai kebutuhan. Pencampuran bahan dilakukan secara bertahap, dimulai dari jumlah yang terendah sampai yang terbanyak 
hingga campuran homogen. Selanjutnya bahan yang telah homogen tadi ditambahkan yang telah dimasak (tidak terlalu panas) secukupnya. Penambahan air dilakukan sambil bahan diaduk merata sehingga bisa dibuat gumpalan-gumpalan. Kemudian adonan pelet dicetak di penggilingan dan diteruskan dengan melakukan pengeringan dengan penjemuran. Setelah kering pelet bisa digunakan untuk pakan ikan, serta pelet yang telah jadi dianalisis proksimat.

\subsubsection{Pemeliharaan Ikan dan Kecernaan Pakan}

Sebelum ikan diberikan pakan uji, terlebih dahulu ikan diadaptasikan di dalam keramba. Setiap keramba diisi ikan uji sebanyak 25 ekor $\backslash \mathrm{m}^{3}$. Adaptasi ikan dilakukan selama satu minggu dan diberi pakan komersil. Selanjutnya ikan ditimbang untuk mengetahui bobot awal. Pemberian pakan dilakukan 3 (tiga) kali sehari yakni pukul 07.00, 12.00 dan 17.00 WIB sebanyak 10\% dari biomassa ikan uji. Pemeliharaan ikan dilakukan selama 56 hari dan setiap 14 hari ikan sampling untuk mengetahui bobot dan jumlah pakan ikan pada minggu selanjutnya.

Ikan uji dipelihara di dalam akuarium dengan padat tebar 10 ekor/wadah dan diberi pakan uji yang telah di tambahkan $\mathrm{Cr}_{2} \mathrm{O}_{3}$ sebanyak $1 \%$. Pakan diberikan $10 \%$ dari biomassa ikan dengan frekuensi pemberian pakan 3 kali sehari yaitu pada pukul 07.00 , 12.00 dan 17.00 WIB. Selanjutnya dilakukan penyiponan 30 menit setelah pemberian pakan untuk mengambil sisa pakan yang tidak dimakan ikan, kemudian dilakukan penyiponan lagi 1-2 jam setelah pakan diberikan untuk mengambil feses ikan. Air yang mengandung feses ikan yang ditampung kemudian dibiarkan sampai feses mengendap, jika feses sudah mengendap air dibuang perlahan dan feses yang mengendap dikeringkan dengan dijemur di bawah sinar matahari. Feses yang telah kering diambil dan dikumpulkan hingga mencapai berat $10 \mathrm{~g}$ untuk dianalisa kandungan $\mathrm{Cr}_{2} \mathrm{O}_{3}$ dan proteinnya.

\subsection{Parameter yang Diamati}

\subsubsection{Kecernaan Pakan (\%)}

Adapun rumus untuk menghitung kecernaan pakan menurut Watanabe (1988), yaitu:

$$
\begin{aligned}
& \mathrm{KP}=(1-\mathrm{a} / \mathrm{a}) \times 100 \\
& \text { Keterangan: } \\
& \mathrm{KP} \quad=\text { Kecernaan Pakan } \\
& \begin{array}{l}
\mathrm{a}, \quad \% \mathrm{Cr}_{2} \mathrm{O}_{3} \text { dalam pakan }(\%) \\
\mathrm{a}, \quad=\% \mathrm{Cr}_{2} \mathrm{O}_{3} \text { dalam feses }(\%)
\end{array}
\end{aligned}
$$

\subsubsection{Kecernaan Protein (\%)}

Kecernaan protein dapat dihitung dengan persamaaan yang dikemungkakan oleh watanabe (1988) sebagai berikut :

\section{Keterangan:}

K.Prot = 1- $\left(a^{\prime} / a^{\prime} \times b^{\prime} / b\right) \times 100$

$$
\begin{array}{ll}
\text { K.Prot } & =\text { Kadar Protein }(\%) \\
\text { a } & =\text { Kadar } \mathrm{Cr}_{2} \mathrm{O}_{3} \text { dalam pakan }(\%) \\
\text { a' } & =\text { Kadar } \mathrm{Cr}_{2} \mathrm{O}_{3} \text { dalam Feses }(\%) \\
\text { b } & =\text { Protein dalam pakan }(\%) \\
\text { b } & =\text { Protein dalam feses }(\%)
\end{array}
$$

\subsubsection{Retensi Protein}

Retensi protein (RP) merupakan perbandingan antara jumlah protein yang disimpan ikan di dalam tubuh dengan jumlah protein yang diberikan melalui pakan. Retensi protein dapat dihitung dengan rumus Watanabe (1988):

$\mathrm{RP}=\frac{\text { Pertambahan bobot protein tubuh }(\mathrm{g})}{\text { Bobot total protein yang dikonsumsi }(\mathrm{g})} \times 100 \%$

\subsubsection{Efisiensi Pakan (\%)}

Jumlah pakan yang diberikan selama penelitian serta berat ikan pada awal dan akhir penelitian akan diperoleh informasi tentang efisiensi pakan. Menurut Watanabe (1988) rumus menghitung efisiensi pakan yaitu:

$$
\mathrm{EP}=\frac{(\mathrm{Bt}+\mathrm{Bd})-\mathrm{Bo}}{\mathrm{F}} \times 100 \%
$$

Keterangan:

$\mathrm{EP}=$ Efisiensi Pakan (\%)

$\mathrm{Bt}=$ Bobot biomassa ikan pada akhir penelitian $(\mathrm{g})$

Bo = Bobot biomassa ikan pada awal penelitian $(\mathrm{g})$

$\mathrm{Bd}=$ Bobot biomassa ikan yang mati selama penelitian $(\mathrm{g})$

$\mathrm{F} \quad=$ Jumlah pakan yang dikonsumsi ikan selama penelitian $(\mathrm{g})$

\subsubsection{Efisiensi Pakan (\%)}

Laju pertumbuhan adalah pertambahan ukuran berat atau panjang ikan pada suatu waktu tertentu. Menurut Hadadi et al. (2007) laju pertumbuhan harian diukur dengan menggunakan rumus : 


$$
\mathrm{LPS}=\frac{(\mathrm{Ln} \mathrm{Wt}-\mathrm{Ln} \mathrm{Wo})}{\mathrm{t}} \times 100 \%
$$

Keterangan:

$$
\begin{aligned}
\mathrm{LPS} & =\text { Laju pertumbuhan spesifik }(\%) \\
\mathrm{Wt} & =\begin{array}{l}
\text { Bobot rata-rata ikan pada akhir } \\
\text { penelitian }(\mathrm{g})
\end{array} \\
\mathrm{Wo} & =\begin{array}{l}
\text { Bobot rata-rata ikan pada awal } \\
\text { penelitian }(\mathrm{g})
\end{array} \\
\mathrm{t} & =\text { Lama penelitian (hari). }
\end{aligned}
$$

\subsubsection{Tingkat Kelulushidupan}

Menurut Kelulushidupan Menurut Effendie (1997) tingkat kelulushidupan dapat dihitung dengan rumus sebagai berikut:

Keterangan:

$$
S R=\frac{N t}{N o} \times 100 \%
$$

$$
\begin{array}{ll}
\mathrm{SR} & =\text { Kelulushidupan (\%) } \\
\mathrm{Nt} & =\text { Jumlah ikan yang hidup pada }
\end{array}
$$

No = $\begin{aligned} & \text { akhir penelitian (ekor) } \\ & \text { Jumlah penan yang hidup pada } \\ & \text { awal pekor) }\end{aligned}$

\subsection{Analisis Data}

Data yang diperoleh selama penelitian disajikan dalam bentuk tabel kemudian dihitung. Selanjutnya data dianalisa secara statistik menggunakan software IBM SPSS versi 22.

\section{Hasil dan Pembahasan}

\subsection{Kecernaan Pakan dan Kecernaan Protein \\ Hasil penelitian menunjukkan bahwa kecernaan pakan berkisar antara 64,03- $68,94 \%$ dan kecernaan protein $79,68-85,01 \%$. Lebih jelas dapat dilihat pada Tabel 2}

Tabel 2. Hasil pengukuran Kecernaan pakan dan Kecernaan Protein

\begin{tabular}{ccc}
\hline Subtitusi TK: TDEGF (\%) & Kecernaan pakan (\%) & Kecernaan protein (\%) \\
\hline $100: 0$ & 64,54 & 79,68 \\
$75: 25$ & 65,99 & 81,80 \\
$50: 50$ & 68,94 & 85,01 \\
$25: 75$ & 64,79 & 80,09 \\
$0: 100$ & 64,03 & 80,11 \\
\hline
\end{tabular}

Tabel 2 menunjukkan bahwa pada P2 dengan perbandingan TK : TDEGF sebesar 50:50 memiliki nilai kecernaan pakan dan protein lebih tinggi dibandingkan perlakuan lainnya. Hal ini diduga disebabkan kandungan protein pada P2 sesuai dengan kebutuhan ikan untuk pertumbuhan dan aktivitas ikan. Menurut Agustono et al. (2010) kombucha juga mengandung bakteri, enzim dan protease yang dapat memecah molekul makanan menjadi senyawa yang lebih sederhana, sehingga ikan mampu nutrisi secara optimal. Hoffman dalam Faradilla (2013) menyatakan bahwa terjadi peningkatan protein yang disebabkan oleh adanya enzim dalam Kombucha yang dapat memecah molekul gula menjadi komponen sederhana yang dapat dimanfatkan untuk perkembangbiakan serta pertumbuhan dari koloni mikroba yang ada dalam Kombucha.

Menurut Agustono et al. (2010) penambahan kombucha pada proses fermentasi eceng gondok dapat menyediakan sumber energi bagi mikroba untuk bekerja pada pakan yang banyak mengandung serat kasar seperti selulosa dan hemiselulosa.
Enzim selulase yang mendegradasi selulosa dalam tepung daun eceng gondok terfermentasi yang dapat mengurangi kadar serat kasar sehingga pakan buatan yang diberikan dapat dicerna dengan baik oleh benih ikan mas.

Hasil penelitan Hutabarat (2017) menyatakan bahwa pemanfaatan tepung daun eceng gondok terfermentasi sebanyak $30 \%$ dalam pakan ikan bawal air tawar memberikan kecernaan pakan sebesar 61,69\%. Selanjutnya pada penelitian Rahmad (2017) kecernaan pakan tertinggi yaitu $67,74 \%$ didapatkan dengan penggunaan tepung eceng gondok terfermentasi sebesar $50 \%$ dalam pakan ikan jelawat. Nilai kecernaan pakan dari setiap perlakuan pada penelitian ini berkisar 20,53 - 60,44\%, secara keseluruhan nilai kecernaan pada penelitian ini lebih rendah dibandingkan dengan pendapat NRC (1993) bahwa kecernaan pakan yang baik adalah $75-95 \%$.

Nilai kecernaan protein pada penelitian ini berkisar 59,77- 80,81\%. Hal ini disebabkan pakan yang diberikan memiliki nilai protein yang sesuai dengan kebutuhan benih ikan mas 
dan dapat di cerna dengan baik sehingga protein dalam pakan dapat dimanfaatkan dengan baik. Menurut Saputra (2014) protein yang mudah dicerna menunjukkan bahwa asam amino yang dapat diserap dan digunakan oleh tubuh tinggi, sebaliknya suatu protein yang sukar dicerna karena sebagian besar akan dibuang oleh tubuh bersama feses. Nilai kecernaan protein yang tinggi sangat penting artinya karena protein merupakan sumber energi utama. Selain digunakan sebagai sumber energi, protein juga digunakan untuk pembentukan sel-sel baru dalam proses pertumbuhan (Marzuqi et al., 2006).

\subsection{Laju Pertumbuhan dan Kelulushidupan Ikan Mas (C. carpio)}

Hasil penelitian menunjukkan bahwa efisiensi pakan berkisar antara 26,64-32,80\%, retensi protein $44,46-52,45 \%$, dan laju pertumbuhan spesifik 2,20-2,76\%. Lebih jelas dapat dilihat pada Tabel 3 .

Tabel 3. Hasil Pengukuran Laju Pertumbuhan dan Kelulushidupan Ikan Mas

\begin{tabular}{ccccc}
\hline TK: TDEGF & \multicolumn{4}{c}{ Parameter yang Diukur } \\
\cline { 2 - 5 }$(\boldsymbol{\%})$ & Efisiensi Pakan (\%) & Retensi Protein (\%) & LPS (\%) & SR (\%) \\
\hline $100: 0$ & $26,64 \pm 0,37^{\mathrm{a}}$ & $44,46 \pm 0,61^{\mathrm{a}}$ & $2,20 \pm 0,02^{\mathrm{a}}$ & 100 \\
$75: 25$ & $29,35 \pm 1,46^{\mathrm{ab}}$ & $45,08 \pm 2,23^{\mathrm{a}}$ & $2,42 \pm 0,08^{\mathrm{b}}$ & 100 \\
$50: 50$ & $32,80 \pm 2,03^{\mathrm{b}}$ & $52,45 \pm 3,21^{\mathrm{b}}$ & $2,76 \pm 0,07^{\mathrm{c}}$ & 100 \\
$25: 75$ & $30,92 \pm 1,01^{\mathrm{b}}$ & $51,07 \pm 1,57^{\mathrm{b}}$ & $2,49 \pm 0,12^{\mathrm{b}}$ & 100 \\
$0: 100$ & $29,46 \pm 2,25^{\mathrm{ab}}$ & $47,91 \pm 3,59^{\mathrm{ab}}$ & $2,45 \pm 0,14^{\mathrm{b}}$ & 100 \\
\hline
\end{tabular}

Keterangan : Nilai yang tertera merupakan rata-rata \pm standar deviasi, huruf yang berbeda pada baris yang sama menunjukkan adanya perbedaan nyata antar perlakuan $(\mathrm{p}<0,05)$

Tabel 3. menunjukkan bahwa efisiensi pakan ikan mas yang terbaik terdapat pada perlakuan P2 lebih tinggi dibandingkan dengan efisiensi pakan pada perlakuan $\mathrm{P} 0$. Hal ini diduga karena pakan mengandung tepung daun eceng gondok terfermentasi yang mampu dimanfaatkan lebih baik oleh ikan. Adanya enzim-enzim yang terkandung dalam tepung daun eceng gondok terfermentasi menggunakan kombucha diduga meningkatkan daya cerna ikan dan kemampuan ikan dalam memanfaatkan pakan yang diberikan. Tinggi rendahnya nilai efisiensi pakan tidak hanya ditentukan oleh jumlah pakan yang diberikan, melainkan juga dipengaruhi oleh beberapa faktor seperti kepadatan, berat individu, umur, suhu, kualitas dan frekuensi pemberian pakan.

Efiensi pakan juga sangat erat kaitannya dengan ketercernaan pakan, menurut NRC (1993) efisiensi pakan berhubungan erat dengan kesukaan ikan akan pakan yang diberikan, selain itu di pengaruhi oleh kemampuan ikan dalam mencerna pakan. Efisiensi pakan pada penelitian ini berkisar 26,64-32,80\%, dimana nilai efisiensi ini tergolong baik dibandingkan penelitian Rahmad (2017) dengan penambahan tepung daun eceng gondok fermentasi sebagai pakan ikan jelawat yang menghasilkan efisiensi pakan $10,4-13,9 \%$.
Tabel 3 dapat dilihat bahwa retensi protein tertinggi terdapat pada perlakuan P2 yaitu $52,45 \%$. Tingginya nilai retensi protein pada P2 hal ini disebabkan karena pakan pada perlakuan ini lebih disukai dan dapat dicerna dengan baik oleh ikan mas. Tepung daun eceng gondok terfermentasi dalam pakan memiliki nilai nutrisi yang baik dan mampu dicerna oleh ikan, hal ini sesuai dengan pendapat Suwarsito dan Anggoro (2005) bahwa makanan yang telah difermentasi memiliki nilai gizi yang lebih tinggi dan daya cerna tinggi sehingga memungkinkan diserap oleh tubuh lebih banyak dan energi yang tersedia dalam tubuh ikan akan lebih tinggi, serta memiliki bau yang khas. Suprayudi (2012), menyatakan bahwa proses fermentasi pada bahan pakan dapat menyebabkan terjadinya perubahan aroma dan rasa. Reaksi antara asam organik dan etanol lainnya yang dihasilkan dari fermentasi akan menghasilkan ester-ester yang merupakan senyawa pembentuk cita rasa dan aroma (Suprihatin, 2010).

Berdasarkan analisis variansi (ANAVA) penggunaan tepung daun eceng gondok terfermentasi dengan menggunakan kombucha dalam pakan ikan mas tidak berpengaruh nyata $(\mathrm{P}>0,05)$ terhadap laju pertumbuhan spesifik. Laju pertumbuhan spesifik ikan mas yang dipelihara di keramba selama penelitian 
berkisar antara 2,20-2,76\%. Hasil penelitian Hurriyatni (2017) menunjukkan bahwa penambahan ragi roti $S$. cerevisiae dalam pakan ikan jelawat yang dipelihara di akurium memberikan laju pertumbuhan spesfik sekitar $1,1-1,3 \%$.

Tepung daun eceng gondok terfermentasi dalam pakan dapat dipecah menjadi asam amino yang lebih mudah diserap oleh ikan jelawat sehingga kebutuhan nutriennya terpenuhi. Zat-zat nutrisi yang dibutuhkan adalah protein, lemak, karbohidrat, vitamin dan mineral (Handjani dan Widodo, 2010). Proses fermentasi dapat merubah substrat bahan tumbuhan yang sulit dicerna menjadi mudah dicerna. Protein sel tunggal akan meningkatkan jumlah protein dalam pakan. Selain itu, proses fermentasi akan menyebabkan pembentukan senyawa-senyawa sederhana yang lebih banyak dibandingkan bahan yang tidak difermentasi (Afriyanto, 2009).

Apabila dibandingkan dengan penelitian sebelumnya Mohapatra (2015) pemanfaatan tepung eceng gondok sebagai pengganti protein dalam pakan benih ikan mas, memperoleh laju pertumbuhan spesifik sekitar $0,5-0,8 \% /$ hari laju pertumbuhan spesifik pada penelitian ini tergolong baik, selanjutnya pada Rahmad (2017) pemanfaatan tepung daun eceng gondok terfermentasi dengan menggunakan cairan rumen sapi dalam pakan ikan jelawat diperoleh nilai laju pertumbuhan spesifik yang tertinggi $0,6 \%$ dengan perlakuan $30 \%$ tepung daun eceng gondok fermentasi dengan cairan rumen sapi, Hutabarat (2017) menyatakan bahwa pemanfaatan tepung daun eceng gondok terfermentasi dalam pakan ikan bawal air tawar, menghasilkan laju pertumbuhan spesifik sekitar 4,2-5,5\%..

Angka kelulushidupan pada penelitian ini tergolong baik jika dibandingkan dengan penelitian Sulhi (2015) substitusi tepung kedelai dengan tepung daun eceng gondok hasil fermentasi dalam formulasi pakan terhadap pertumbuhan dan sintasan benih gurame memperoleh angka kelulushidupan sekitar 76,32-91,43\% dan Syahrizal (2017) dampak pemberian tepung daun eceng gondok dalam pakan buatan bagi perubahan warna dan kelangsungan hidup ikan mas koki (Carassius auratus) memperoleh angka kelulushidupan sekitar 93,30-100\%.

\section{Kesimpulan dan Saran}

Hasil penelitian menunjukkan bahwa pemberian tepung eceng gondok terfementasi kombucha dalam pakan buatan dengan dosis berbeda sebagai subtitusi tepung kedelai memberikan pengaruh terhadap pertumbuhan dan kelulushidupan ikan mas. Hasil terbaik terdapat pada P2 (Tepung eceng gondok 50\%: tepung kedelai $50 \%$ ) dengan nilai kecernaan pakan $(68,94)$, kecernaan protein $(85,01)$, nilai efisiensi pakan $(32,80 \pm 2,03)$, retensi protein $(52,45 \pm 3,21)$, laju pertumbuhan spesifik $(2,76$ $\%$ /hari), dan Kelulushidupan $100 \%$. Kesimpulan dari penelitian menunjukkan bahwa tepung eceng gondok terfermentasi sebanyak $50 \%$ mampu menggantikan tepung kedelai dalam pemeliharaan ikan mas.

Sebaiknya dilakukan penelitian lanjutan tentang pemanfaatan tepung daun eceng gondok terfermentasi dalam pakan terhadap jenis ikan lainnya.

\section{Daftar Pustaka}

Afrianto. (2009). Pakan Ikan. Edisi ke 5. Kanasius. Yogyakarta

Agustono., A.S. Widodo, dan W. Paramita. (2010). Kandungan Protein Kasar dan Serat Kasar pada Daun Kangkung Air (Ipomoea aquatica) yang Difermentasi. Jurnal Ilmiah Perikanan dan Kelautan, 2(1): 37- 43 .

Astuti, R.D. (2008). Analisis Kandungan Nutrisi pada Eceng Gondok. Institut Pertanian Bogor. Bogor. $18 \mathrm{hlm}$

Faradilla. (2013). Fermentation and Food Safety Aspen Publiser Inc : Maryland.

Fitrihidajati, H., E. Ratna, Isnawati dan G. Soeparto. (2015). Kualitas Hasil Fermentasi pada Pakan Ternak Ruminansia Berbahan Baku Eceng Gondok (Eichornia crassipes). Journal of Biology \& Education. Biosaintifika, $7(1)$.

Handajani, H dan Widodo. (2010). Nutrisi Ikan. UMM Press. Malang $271 \mathrm{hlm}$

Hurriyanti, Y. (2017). Evaluasi Penambahan Ragi Roti Saccharomyces cerevisiae dalam Pakan terhadap Kinerja Pertumbuhan Benih Ikan Jelawat (Leptobarbus hoevenii). Seminar Nasional Penerapan Ilmu Pengetahuan dan Teknologi.

Hutabarat, H.D. (2017). Pemanfaatan Tepung Daun Eceng Gondok (Eichhornia 
crassipes) Terfermentasi Menggunakan Cairan Rumen Sapi dalam Pakan terhadap Pertumbuhan Benih Ikan Bawal Bintang Air Tawar (Colossoma macropomum). Skripsi. Fakultas Perikanan dan Kelautan. Universitas Riau. Pekanbaru. 16 hlm.

NRC. (1993). Nutrition and Requirement of Warmwater Fishes. National Academic of Science. Washington, D. C. 248 hlm.

Marzuqi, M., N.A. Giri, dan K. Suwirya. (2006). Kebutuhan protein dalam pakan untuk pertumbuhan yuwana ikan kerapu batik (Epinephelus polyphekadion). Jurnal Peneltian Perikanan Indonesia, $9(1): 25-32$.

Muchtaromah, B., R. Susilowati, dan Kusumastuti. (2006). Pemanfaatan Tepung Hasil Fermentasi Eceng Gondok (Eichornia crassipes) sebagai Campuran Pakan Ikan untuk Meningkatkan Berat Badan dan Daya Cerna Protein Ikan Nila Merah (Oreochromis Sp). El-Qudwah, 10:110.

Muskita, W.H. (2012). Substitusi Tepung Bungkil Kedele, Glycine max, dengan Tepung Bungkil Biji Kapuk, Ceiba Petandra, dalam Pakan Juvenil Udang Vaname Litopenaeus vannamei : Kajian Histologi, Enzimatik dan Komposisi Asam Lemak. Disertasi. Bogor (ID): Institut Pertanian Bogor.

Pratama, R.I., I. Rostini, dan M.Y. Awaluddin. (2013). Komposisi Kandungan Senyawa Flavor Ikan Mas (Cyprinus carpio) Segar dan Hasil Pengukusannya. Jurnal Akuatika, 4(1) :55-67.

Priskila, (2007). Pengaruh Penggunaan Kombucha terhadap Kandungan Protein Kasar dan Serat Kasar pada Fermentasi Daun Talas (Colocasia Esculenta). Skripsi. Universitas Airlangga.

Rahmad, F.A. (2017). Pemanfaatan tepung eceng gondok (Eichhornia crassipes) terfermentasi menggunakan cairan rumen sapi dalam pakan terhadap pertumbuhan benih ikan patin siam (Pangasius hypophthalmus). Skripsi. Fakultas Perikanan dan Kelautan. Universitas Riau
Saputra, D. (2014). Penentuan Daya Cerna Protein In-Vitro Ikan Bawal Air Tawar (Colossoma macropomum) pada Umur Panen Berbeda. Jurnal Comtech, 5(2): 1127-1133.

Suprayudi, M.A. (2010). Bahan baku lokal: Tantangan dan harapan akuakultur Indonesia. Abstrak. Prosiding Simposium Nasional Bioteknologi Akuakultur III 2010, Bogor, 7 Oktober 2010, $31 \mathrm{hlm}$.

Suprayudi, M.A., G. Endriani, dan J. Ekasari. (2012). Evaluasi Kualitas Air Produk Fermentasi Berbagai Bahan Baku Hasil Samping Agroindustri Lokal: Pengaruhnya terhadap Kecernaan Serta Kinerja Pertumbuhan Juvenil Ikan Mas. Jurnal Akuakultur Indonesia, 11(1):110.

Suprihatin. (2010). Teknologi fermentasi. UNESA University press, $43 \mathrm{hlm}$.

Suwarsito dan S. Anggoro. (2005). Pemanfaatan Ampas Tahu dengan Metode Fermentasi untuk Bahan Baku Ikan Lele. Laporan Penelitian. Universitas Muhammadiyah Purwokerto. Purwokerto.

Syahrizal. (2017). Dampak Pemberian Tepung Eceng Gondok (Eichhornia crassipes) dalam Pakan Buatan Bagi Perubahan Warna dan Kelangsungan Hidup Ikan Mas Koki (Carassius auratus). Jurnal Akukultur Sungai dan Danau, 2(2):7282.

Trivela. M. (2018). Subtitusi tepung Kedelai dengan Tepung Daun Eceng Eondok (Eichhornia crassipes) terfermentasi menggunakan Cairan Rumen Sapi dalam pakan untuk Pertumbuhan Benih Ikan Jelawat (Leptobarbus hoevenii blkr). Skripsi. Fakultas Perikanan dan Kelautan. Universitas Riau.

Watanabe, T. (1988). Fish Nutrition and Marine Culture. Departement of Aquatic Biosciencis Fisheries. University of Tokyo. 233 pp. 